This is the version of the article accepted for publication in World Trade Review published by Cambridge

University Press: https://www.cambridge.org/core/journals/world-trade-review

Accepted version downloaded from SOAS Research Online: http://eprints.soas.ac.uk/30163

\title{
Reimagining the Framework for Resolving Intra-African Commercial Disputes in the Context of the African Continental Free Trade Area
}

\section{Agreement}

\section{Introduction}

The Agreement Establishing the African Continental Free Trade Area (AfCFTA) was signed on 21 March 2018 by 44 African countries, members of the African Union ${ }^{1}(\mathrm{AU}){ }^{2}{ }^{2}$ Recently at the $31^{\text {st }}$ African Union Summit at Nouakchott, five additional African states signed the Agreement. ${ }^{3}$ The Agreement has been ratified by six states and will come into force when it is ratified by 22 states. ${ }^{4}$ The parties agreed a number of Protocols to the Agreement. ${ }^{5}$ The Agreement provides a mechanism for the settlement of disputes, but between its member states and not by private commercial entities. However, it is these private entities who will engage in the actual trade in goods, services and investments across the continent. The interaction of private parties will invariably give rise to commercial or business disputes. This makes it necessary to examine whether the current framework for the resolution of intra-African commercial disputes is fit for purpose and whether the framework can be improved to enable it deliver on the goals of the AfCFTA. This article particularly examines the framework for resolving intra-African commercial disputes.

This article in section A briefly introduces the AfCFTA and mentions some of the legal and non-legal barriers to the access and growth of intra-African trade in goods and services, and some of the steps being taken at the continental level to address these issues. This is in recognition of the fact that the primary purpose of the AfCFTA is to remove the barriers to the free flow of trade in goods, services and investment within the African continent. ${ }^{6}$ Section $B$ mentions some of the types of private economic actors that operate in the African market as examples of those entities that will drive the growth of this free flow of trade in goods and services across the African continent. These entities will most likely, be the disputants in the framework for dispute resolution as reimagined in this article. Section $\mathrm{C}$ critically examines the current framework for the resolution of disputes arising from such

\footnotetext{
${ }^{1}$ There are 54 African states but the AU recognises the Western Sahara as a member state bringing its member states to 55. The AfCFTA signatory states are listed under Table 3 below.

2 The Continental Free Trade Area is one of the twelve flagship projects/initiatives of the African Union (AU) for the implementation of its Agenda 2063 adopted at the 50th anniversary of the AU on 13 June 2013. Agenda 2063 sets out the aspirations of African states' leaders for the transformation of the continent and its peoples over the next 50 years. See for more information: https://au.int/en/agenda2063 [last visited 26 July 2018]. ${ }^{3}$ These five states are: South Africa, Sierra Leone, Namibia, Lesotho and Burundi. The $31^{\text {st }}$ African Union Summit concluded on 02 July 2018.

${ }^{4}$ In accordance with art. 24 of the AfCFTA Agreement. The six ratifications are by: Kenya, Ghana, Rwanda, Niger, Chad and Swaziland.

${ }^{5}$ The Protocols on Trade in Goods, Trade in Services and the Rules and Procedures on the Settlement of Disputes were agreed. Phase 2 of the negotiations which commenced in August 2018 will focus on investment, competition policy and intellectual property rights.

${ }^{6}$ The barriers are tariffs, non-tariff barriers and non-tariff measures, which include the use of quotas, embargoes, sanctions, and licenses, that impede the free flow of trade in goods and services across African states.
} 
commercial transactions on the continent. It determines whether the current framework can efficiently serve the expected growth in disputes arising from increased intra-African trade with the implementation of the AfCFTA. Two proposals for a more efficient continental arbitration regime are made in Section D. The first proposal is for the designation of some arbitration centres as Regional Arbitration Centres (RAC) which will be located across the eight Regional Economic Communities (RECs) recognised by the $\mathrm{AU}$; and the second proposal is for the establishment of a continental African Commercial Court (ACC) which will have the limited jurisdiction to enforce or annul the final awards from such arbitral references.

\section{A. The African Continental Free Trade Agreement (AfCFTA)}

The AfCFTA aims at 'integrating Africa's markets', to 'strengthen our economic relations', and to create 'a continental market with the free movement of persons, capital, goods and services'. ' The signing of the agreement on the AfCFTA signalled the move towards the attainment of part of the vision of the heads of governments of African states, as articulated in the African Union (AU) Agenda 2063 for, 'An integrated, prosperous and peaceful Africa, driven by its own citizens and representing a dynamic force in the international arena. ${ }^{8}$ This vision enables African governments to work towards creating, at the continental level, the necessary environment for private agencies and entities to conduct business across the African continent.

The AfCFTA Protocol on Rules and Procedures on the Settlement of Disputes creates a Dispute Settlement Body (DSB) and a Dispute Settlement Panel (DSP) to determine, 'disputes arising between State Parties concerning their rights and obligations under the provisions of the Agreement'. ${ }^{9}$ This provision limits the scope of the dispute and nature of the parties that can access the dispute resolution mechanism under the Protocol. It leaves out commercial disputes between the private actors who engineer and facilitate the trade in goods and services across the African continent. The vast majority of such transactions will fall within the trade in goods dichotomy. The nature of the disputes arising from such transactions are primarily private and not public which will otherwise engage the regulatory actions or measures imposed by a state (acta jure imperii). The disputes arising from the effect of such regulatory measures on a foreign investor, will fall within the investment dispute settlement regime. ${ }^{10}$

The AfCFTA seeks to remove both legal and non-legal barriers to trade in Africa. There are several legal and non-legal barriers to trade in goods and services generally and in particular for intra-African trade. According to Roberto Longo and Khalid Sekkat, the obstacles to intra-African trade include,

insufficient or non-existing transport and communications networks; the existence of the multiplicity of non-convertible currencies for countries outside the CFA franc zone; ethnic,

\footnotetext{
${ }^{7}$ Preamble to the AfCFTA.

${ }^{8}$ Preamble to The AU 2063 Agenda titled, The Africa We Want, with the vision of, "an integrated, prosperous and peaceful Africa, driven by its own citizens and representing a dynamic force in international arena". ${ }^{9}$ Art. 3 of the Protocol.

${ }^{10}$ On investment dispute settlements, see for example, Rudolf Dolzer \& Christoph Schreuer, Principles of International Investment Law, (2 ${ }^{\text {nd }}$ ed., Oxford University Press, 2012). We note the current backlash against the investor-state dispute settlement of arbitration and the different proposals on fixing or abandoning the mechanism. See UNCITRAL Working Group III: Investor State Dispute Settlement Reform, documents at: https://uncitral.un.org/en/working groups/3/investor-state [last visited 17 December 2018].
} 
cultural and linguistic diversity; and very high political instability ... (including) new sets of variables: infrastructure, economic policy and threats to political stability. ${ }^{11}$

The issues on this list are all acknowledged to have a negative impact on intra-African trade..$^{12}$ Other notable barriers include, the exportation of primarily raw materials and commodities by African states, lack of available markets for the conversion of such raw materials into finished goods within Africa, competition between African states for access to the same foreign markets, lack of value addition chains, and heavy dependence on the importation of finished or processed goods from non-African countries, ${ }^{13}$ all of which negatively affect their balance of payments. ${ }^{14}$

The AfCFTA Agreement marks an important milestone for Africa. This is because all relevant datasets confirm the very low level of intra-African interaction as it relates to wealth creation activities such as exchanges in trade in goods, services, and investment. ${ }^{15}$ This is irrespective of the fact that African states are geographically closer to each other than they are to their colonialist countries with whom they all maintain higher trading levels. It is this reality which makes the signing of the AfCFTA exciting and a welcome development. This is irrespective of the delay by one of the major economies on the continent in signing the Agreement. ${ }^{16}$

Article 21 of the AfCFTA refers to dispute settlement and establishes a dispute settlement mechanism (DSM) akin to the mechanism used under the World Trade Organisation (WTO) Instruments. ${ }^{17}$ The AfCFTA DSM system applies, 'to the settlement of disputes arising between state Parties'. The reference to state Parties as possible disputants under the DSM system, essentially removes from its purview, commercial disputes arising from exchanges or trade in goods and services between private actors. This is understandable because (just like any other Free Trade Agreement, FTA) the AfCFTA deals with public law actors (states) and public law issues (for example, tariffs) relevant to the elimination of barriers to, and the facilitation of trade in goods and services, and investments within

\footnotetext{
${ }^{11}$ Roberto Longo \& Khalid Sekkat, 'New Forms of Co-operation and Integration Emerging in Africa: Obstacles to Expanding Intra-African Trade', OECD Technical Working Paper No. 169 of 29 March 2001, p. 10. Their study was based on dataset from 41 African countries between 1989 and 1997.

12 On the impact of trade policy (and other issues) on the growth of African trade, see the various contributors in Patrick Low, Chiedu Osakwe and Maika Oshikawa (eds.), African Perspectives on Trade and the WTO:

Domestic Reforms, Structural Transformation and Global Economic Integration, (Cambridge University Press, 2016).

${ }^{13}$ The World Trade Organisations (WTO) recent Trade Facilitation Agreement will assist with reducing governmental 'red tape' through the "simplification, modernisation and harmonisation of export and import processes" of its member States which will fix some of the NTBs but not some of these enumerated endemic barriers to intra-African trade. For the WTO trade facilitation regime see, https://www.wto.org/english/tratop e/tradfa e/tradfa e.htm [last visited 26 July 2018].

${ }^{14}$ See for example, M. Sornarajah, The International Law on Foreign Investment, (3rd ed., Cambridge University Press, 2012) at p. 310, for the need for developing countries to maintain their balance of payments safeguard in the context of foreign investors repatriating their profits to their home states.

${ }^{15}$ See for example, the United Nations Economic and Social Council (UNESCO) 2015 Progress Report on IntraAfrican Trade available at:

http://repository.uneca.org/bitstream/handle/10855/22959/b11553832.pdf?sequence=1 [last visited 26 July 2018].

${ }^{16}$ Nigeria is yet (but expected) to sign the Agreement.

${ }^{17}$ The United Nations Commission on Trade and Development (UNCTAD) had proposed that the WTO DSM mechanism system should be adopted under the AfCFTA. See UNCTAD Publication, 'African Continental Free Trade Area: Policy and Negotiation Options for Trade in Goods', (2016) available at:

http://unctad.org/en/PublicationsLibrary/webditc2016d7 en.pdf [last visited 26 July 2018].
} 
the African continent. ${ }^{18}$ The Agreement engages with actions that fall within the remit of the state and its regulatory and fiscal powers. ${ }^{19}$ This leaves out the micro-level engagement of private actors who execute the trade in goods and services and make the necessary investments, across the borders of African states. These private actors are physical and legal persons which may include a state entity acting in a commercial capacity.

It is recognised that the primary actor that suffers the effects of the imposition of a tariff or non-tariff measure, which breaches the provisions of the AfCFTA, will usually be a physical or legal person, who will not have standing (in their personal capacity) before the DSM. ${ }^{20}$ The question that therefore arises is whether the African state whose citizen has suffered loss as a result of such measures can espouse the claims of its citizen. Jurisprudence from the WTO DSM does not technically preclude such espousal, which can also be on the basis of diplomatic protection. ${ }^{21}$ The primary question is whether it will be desirable for states to use the DSM provided under the AfCFTA to espouse the claims of their citizens. In some situations, it may be preferable that a state or group of states pursue redress for their citizens via the DSM against another state or group of states. But in the vast majority of cases, the dispute will fall within the commercial contract between the transacting parties. The discussion in this article focuses on the participation of these private actors in the provision of intra-African trade in goods and services, and investment, and explores the need for an appropriate and modern dispute resolution mechanism that will support the growth of intra-African trade.

\section{B. Intra-African Commercial Actors}

This section briefly sets out the types of economic actors that operate in the African market space and explores their participation in intra-African trade in goods, services and investment, which will drive the success of the AfCFTA. According to the United Nations Conference on Trade and Development (UNCTAD), with the AfCFTA,

Intra-African trade is expected to rise by US\$ 34.6 billion (52.3 per cent above the 2022 baseline), if agriculture/food, industrial goods and services are included, with the highest impact being in industrial goods (as US\$ 27.9 billion, or 52.3 per cent above the baseline). ${ }^{22}$

It is recognised that this increase in trade will be driven by small and medium sized firms and new tech start-ups. ${ }^{23}$ The legal status of corporations or business entities trading or carrying on business across one or more African countries vary from the informal to the formal. These include family businesses,

\footnotetext{
${ }^{18}$ According to arts. 6 and 7 of the AfCFTA, the Agreement covers Trade in Goods, Trade in Services, Investment, Intellectual Property Rights and Competition Policy, with a protocol for each (including the Protocol on the Rules and Procedures for the Settlement of Disputes) when negotiated, to be annexed to the Agreement.

${ }^{19}$ For example, art. 4 imposes tasks on the state parties of the AfCFTA which will lead to the realisation of the objectives of the Agreement as set out in art. 3 AfCFTA.

${ }^{20}$ Art. 21 of the AfCFTA expressly states that the DSM, "shall apply to the settlement of disputes arising between the State Parties".

${ }^{21}$ One example is from the Banana disputes where it was acknowledged that individual exporters were pursuing the claim. On the dispute, see: https://www.wto.org/english/tratop e/dispu e/cases e/ds27 e.htm [last visited 26 July 2018].

22 United Nations Conference on Trade and Development (UNCTAD), African Continental Free Trade Area: Policy and Negotiation Options for Trade in Goods, UNCTAD/WEB/DITC/2016/7 at p.14

${ }^{23}$ See for example, the research paper: Henry Thompson, Ben Shepherd, Gita Honwana Welch, and Adjoa Anyimadu, 'Developing Businesses of Scale in Sub-Saharan Africa: Insights from Nigeria, Tanzania, Uganda and Zambia', The Royal Institute of International Affairs, Chatham House, September 2017, which identified, "limited access to mid-scale finance for SMEs, a lack of capable managers, poor infrastructure, a constrained pool of skilled workers and corruption" as common constraints to businesses in the countries they studied.
} 
micro, small and medium sized enterprises (MSME) that, constitute the vast majority of business entities, as well as large companies. ${ }^{24}$ These corporations are active in the agricultural, telecommunications, banking, retail and mining sectors and some of them transact across several African states. ${ }^{25}$ Technology companies are also gaining ground on the continent. Forbes.com lists the following as the top new tech start-ups in Africa: VConnect, MeQasa, Flutterwave, Sliide Airtime, Printivo, and LIfeQ. ${ }^{26}$ Therefore there is good basis for the prediction of the growth of cross border or intra-African trade.

In addition to the big and emerging corporations are the small and medium sized enterprises (SME) across the continent. These extend their transactions beyond one state, especially across neighbouring countries. They usually trade within the same Regional Economic Community (REC). In discussions on intra-African trade flows, we must not discount the role of operators (who are mainly individuals) in the informal sector. African states have very large informal sectors in which citizens transact outside the formal monetary and legal systems. ${ }^{27}$ Such enterprises are usually not registered under the law, may not operate a bank account, keep few or no records of their transactions, employ casual labour and lack access to legal advice and or financial services. ${ }^{28}$ However such informal business entities make a major impact on the development and living standards of a very large proportion of African citizens. ${ }^{29}$ For example, these informal businesses create jobs (usually low skilled jobs) which aid the human development of African citizens.

These examples show that there are different types and sizes of actors operating in the commercial spaces across the African continent. These range from the big business entities that may have formal presence in more than one African country, have access to legal, financial and insurance services, to the smaller business entities that do not have such formalised presence nor access to relevant support services. The ability to access such business support services (legal, financial and insurance) also impact on the type of dispute resolution process the actors resort to when a commercial dispute arises.

\section{Resolution of Intra-African Commercial Disputes}

The discussion in this section will focus on disputes arising from purely private commercial transactions. Such disputes will typically be between two or more private, commercial or business

\footnotetext{
${ }^{24}$ According to a 2016 study by McKinsey Global Institute, 56\% of the largest companies in Africa are wholly owned by Africans and these operate in food and agricultural sector. State owned enterprises account for $17 \%$ of these companies and operate mainly in resources, utilities and transportation sectors. The remaining $27 \%$ are foreign-based multinational corporations. See: https://qz.com/782196/mckinseys-africa-2016-reporthighlights-africas-fast-growing-corporate-companies/ [last visited 26 July 2018].

${ }^{25}$ See the various stock exchanges in Africa for the list of some of these corporations.

${ }^{26}$ See: https://www.forbes.com/sites/montymunford/2017/10/18/these-are-the-top-african-tech-startupsyou-need-to-know-about/2/\#439b2e8b1983 [last visited 26 July 2018].

${ }^{27}$ According to a 2017 study published under the IMF Working Papers series by, Leandro Medina, Andrew Jonelis and Mehmet Cangul, "The Informal Economy in Sub-Saharan Africa: Size and Determinants, WP/17/156. The authors applied the light density approach and the predictive mean matching method to measure the size of the informal economies of Sub-Saharan African countries over 24 years and found that the size ranges from $20 \%$ to $65 \%$. For more details see:

https://www.imf.org/en/Publications/WP/Issues/2017/07/10/The-Informal-Economy-in-Sub-Saharan-AfricaSize-and-Determinants-45017 [last visited 26 July 2018].

${ }^{28}$ See for an example of the definition of the informal sector, the International Labour Organisation (ILO) at http://www.ilo.org/ilostat-files/Documents/description IFL EN.pdf [last visited d 26 July 2018].

${ }^{29}$ See for example, Henry Thompson, Ben Shepherd, Gita Honwana Welch and Adjoa Anyimadu, 'Developing Businesses of Scale in Sub-Saharan Africa: Insights from Nigeria, Tanzania, Uganda and Zambia', Chatham House Research Paper available at: https://www.chathamhouse.org/publication/developing-businesses-scalesub-saharan-africa-insights-nigeria-tanzania-uganda-zambia [last visited 26 July 2018].
} 
entities. It may also include a state or a state agency performing a commercial transaction and acting in a commercial capacity. The current framework for the resolution of such commercial disputes are through litigation before national courts (1), mediation (2) or arbitration (3). For completeness, investment disputes between African states and African investors may also arise under these transactions and these may be resolved through investment arbitration (4).

\section{Litigation}

The 54 independent African countries all have a State sponsored judiciary with clearly defined court hierarchies. In the vast majority of African states, these court structures are contained in their written constitutions which also provide detailed appeal structures ${ }^{30}$ Citizens of African states generally have constitutionally protected rights of access to their national courts to pursue the vindication of their legal rights. However, the timeline for pursuing claims before the courts of most African states is notoriously long, ${ }^{31}$ with most of the judicial systems dating back to the colonial period, and with very little modernisation having been made. This inefficiency in the court systems is balanced with low court fees (in comparison to court fees payable in developed jurisdictions) which supports access to the courts and litigation as the primary dispute resolution mechanism.

One major disadvantage of cross-border litigation is that each African state has a different legal system as part of its colonial heritage. The vast majority of the continent was colonised and the colonisers introduced their own legal systems, laws and court structures in their colonies. This gave to the different African countries the civil ${ }^{32}$ or common ${ }^{33}$ law or Roman-Dutch ${ }^{34}$ legal systems. In some states, the Sharia and customary laws also play central roles in the judicial process and systems. ${ }^{35}$ To add further to the complexity, in some states, their Supreme courts lack jurisdiction over some types of business laws so that a supranational court determines disputes arising from such business transactions. ${ }^{36}$ This is the position in all seventeen OHADA member states, ${ }^{37}$ where the Common Court of Justice and Arbitration (CCJA) is the court of final jurisdiction over all matters falling within the OHADA Uniform Acts. ${ }^{38}$

\footnotetext{
${ }^{30}$ For some examples, see: Part VII of the 1999 Constitution of the Federal Republic of Nigeria (as amended); Chapter 11 of the 1992 Constitution of Ghana; Title VI of the 1990 Constitution of Benin Republic; Chapter 10 of the 2010 Constitution of Kenya; and Part 3 of Chapter 3 of the 2012 Constitution of Egypt.

${ }^{31}$ One notable exception is Rwanda. According to the World Bank Ease of Doing Business Report, 2018, it takes 280 days from the filing of a dispute to the payment of the judgment sum. See: http://www.doingbusiness.org/data/exploreeconomies/rwanda\#enforcing-contracts [last accessed 26 July 2018].

${ }^{32}$ For example, in the Francophone countries of Benin Republic, Mali, Cote d'Ivoire.

${ }^{33}$ For example, Kenya, Uganda, Ghana and Nigeria.

${ }^{34}$ For example, South Africa.

${ }^{35}$ For example, The Gambia and, Mauritania.

${ }^{36}$ Notably under the OHADA regime with the Common Court of Justice and Arbitration.

${ }^{37}$ The seventeen OHADA member States are: Benin, Burkina Faso, Cameroon, Central Africa Republic, Chad, Comoros, Congo Brazzaville, Congo, Cote d'Ivoire, Equatorial Guinea, Gabon, Guinea, Guinea Bissau, Mali, Niger, Senegal, and Togo.

38 On OHADA, see Emilia Onyema, 'Arbitration under the OHADA Regime', International Arbitration Law Review, (2008) p. 205; Renuad Beachard \& MJV Kodo, 'Can OHADA Increase Legal Certainty in Africa?' available online at: http://documents.worldbank.org/curated/en/266761467990085419/Can-OHADA-increaselegal-certainty-in-Africa [last visited 26 July 2018].
} 
In addition to differences in legal systems, there are barriers of language ${ }^{39}$ and rights of audience before the national courts. ${ }^{40}$ With regards to litigation, in any jurisdiction in the world, lawyers need to be qualified in the particular jurisdiction to enable them to represent their clients in litigation before national courts. The routes to legal qualification (or applicable exemptions) usually differ, being national in context. The most critical hindrance to cross-border litigation however, is the lack of a continental treaty on the enforcement of court judgments issued in one African country in another African country. This negatively impacts on the enforcement of court judgments arising from cross border litigation and thus severely limits the negotiability of national court judgments across Africa. There is no African state that is party to either the Hague Convention on the Recognition and Enforcement of Foreign Judgments in Civil and Commercial Matters of $1971,{ }^{41}$ or the Hague Convention on Choice of Court Agreement, 2005. ${ }^{42}$ Both conventions enable the recognition and enforcement of court judgments from one convention state in another. African states may choose to join either of these two conventions to ease the enforcement of cross border court judgments. Alternatively, the AfCFTA may be an opportunity for African states to explore the possibility of negotiating such a treaty which will create a legal regime for the free movement of court judgements across the continent.

To these differences and complexities, we can add the lack of familiarity with the legal systems across the African continent, by lawyers outside each jurisdiction. It is misconceived for any party to presume that the same legal regime applies, and in the same way, in one particular country, as in other African countries. It is this same issue of difference that makes the harmonisation regime under the OHADA Treaty attractive. This is because as it relates to business laws, the same text applies in those eleven areas of law where uniform acts are in effect in the OHADA jurisdictions and one supranational court interprets the texts. ${ }^{43}$ The East African Community Court of Justice (EACJ) is another supranational court operational within the East African Community (EAC) comprising of Burundi, Kenya, Rwanda, Tanzania and Uganda. One jurisdiction of the EACJ is to take referrals from its constituent national courts and make preliminary rulings in the interpretation of EAC laws. ${ }^{44}$ Similar to the OHADA CCJA, natural and legal persons have standing before the EACJ. ${ }^{45}$ However, the EACJ will not determine commercial disputes arising between two or more trading parties which dispute does not engage EAC law. The EACJ however, has jurisdiction to sit as an arbitral tribunal with its judges acting as arbitrators, over commercial disputes. ${ }^{46}$

The current reality however, is that only 17 of the 54 African states have harmonised their business laws with a supranational court as the final arbiter of disputes arising from the business laws. One

\footnotetext{
${ }^{39}$ In almost all African countries, one or more European languages have been adopted as the formal language with English, French and Portuguese, and Arabic spoken in different states.

${ }^{40}$ Some of these non-legal barriers include: ease (or lack thereof) of movement across African borders; distrust based on ethnicity and political affiliations; and preference for all that is Western and what is popularly and colloquially referred to as 'colonial mentality'.

${ }^{41}$ This Hague Convention has only been ratified by five countries and entered into force on 20 August 1979.

42 This Hague Convention has 35 contracting parties and came into force on 1 October 2015.

43 The ten areas of business laws so far regulated are: Law of cooperative societies; General commercial law; Law of commercial companies and economic interest groups; Law of secured transactions and guarantees; Simplified recovery procedures and measures of execution; Collective proceedings for clearing of debts; Arbitration law; Mediation law; Organisation and harmonisation of accounting firms; and contract of carriage of goods by road.

${ }^{44}$ In accordance with art. 34 of the Treaty for the Establishment of East African Community, 1999 (as amended).

45 In accordance with art. 30 of the EAC Treaty

${ }^{46}$ In accordance with art. 32 of the EAC Treaty.
} 
practical way for litigants to ameliorate the impact of the differences mentioned above, on their crossborder transactions, is to refer to local lawyers. Such referral will add to their transactions cost and cost of dispute resolution. This will have a negative impact on MSMEs and operators in the informal sector who are the main drivers of intra-African trade in goods and services. Cross-border intra-African litigation, is therefore, not the best dispute resolution mechanism to adopt.

\section{Mediation}

In this article, the word, 'mediation' is used in a very broad sense to refer to all non-adjudicative alternative dispute resolution (ADR) processes. ${ }^{47}$ The basic idea behind all such processes is to empower the disputants to manage their dispute and its resolution either by themselves or with the intervention of a third party neutral. ${ }^{48}$ Such processes align well with traditional dispute resolution processes of various pre-colonial African communities. ${ }^{49}$ These traditional processes (which remain in use) are applied to resolve all types of disputes including, civil, family, communal and commercial disputes. With reference to the enforcement of decisions from such traditional dispute resolution processes, each community formulated its own enforcement measures. ${ }^{50}$ In post-colonial Africa, enforcement of the outcomes of some of these processes, for example, customary arbitration, can be enforced through the formal justice systems and national courts.

The primary advantage of mediation and similar processes is the settlement of disputes through a non-acrimonious process that may encourage the retention of the relationship between the disputants going forward. In this sense, it serves to preserve business relationships and transactions, and protect community cohesion. ${ }^{51}$ For those parties who wish to, and can, this process gives disputants power over the resolution of their dispute and can be informal and not overly technical or legalistic. However, the major disadvantage of these processes (in their modern iteration) is their lack of definitive and self-enforceable outcome. In mediation, a settlement may be reached, but such settlement, not being an imposed decision, relies on the will of the parties for its performance. This is a primary disadvantage which, commercial parties will not desire, since it lacks certainty and finality. ${ }^{52}$

Does this imply that mediation and similar processes are not useful in commercial dispute resolution? We do not think so. In our view, dispute resolution processes can be organised on a spectrum from the informal (bilateral negotiations) to the formal (litigation before state courts). There are several

\footnotetext{
${ }^{47}$ Such processes are conciliatory in outlook though mediation is the best known of such processes.

${ }^{48}$ The third party neutral is usually referred to as a mediator and can adopt a facilitative or interventionist approach. Roberts and Palmer, in distinguishing between the arbitrator and mediator note, "Whereas the arbitrator assumes power to make decisions for the parties to a dispute, no such power is surrendered to the mediator; ultimate control over the outcome remains with the parties themselves. But this line may be obscured in real-life processes, particularly where the rank or posture of the intervener may make the nature of the intervention, and hence the location of power over an outcome, appear uncertain". See Simon Roberts and Michael Palmer, Dispute Processes: ADR and the Primary Forms of Decision-Making, (2 ${ }^{\text {nd }}$ ed., Cambridge University Press, 2005) at p. 158.

${ }^{49}$ See for example, Agyemang Attah-Poku, African Ethnicity, History, Conflict Management, Resolution and Prevention, (University Press of America, Inc., 1998); Teslim O. Elias, The Nature of African Customary Law, (Manchester University Press, 1956).

${ }^{50}$ Such enforcement measures included ostracisation which was effective because of the close communal interaction of members of such communities.

51 The community here refers to the group of traders or business entities engaged in the same trade.

52 UNCITRAL in recognition of this limitation of settlement agreements, recently agreed the text of the United Nations Convention on International Settlement Agreements Resulting from Mediation 2018. In addition, UNICTRAL published a Model Law on International Commercial Mediation and International Settlement Agreements Resulting from Mediation, 2018 (Amending the Model Law on International Commercial Conciliation, 2002).
} 
other processes in between the two ends of the spectrum. And since most transacting parties have become more sophisticated, and can buy legal advice and insurance, it is our view that the state can safely entrust them with formulating or fashioning the dispute resolution processes that they feel will better serve their particular purposes and needs. On this understanding, most states grant commercial disputants powers over their choice of dispute resolution tools and mechanisms, and provide a supportive court that, subject to their public policy norms, will lend their powers to support the processes and enforce the outcomes.

This shift in the position and outlook of states, as it relates to dispute resolution processes and giving effect to their outcomes, is the policy that underpins regimes that enforce settlements from these processes (including enforcement of arbitral awards). One example from Lagos State (Nigeria) is the court annexed mediation process of the Multidoor Court House and the enforcement of the settlement agreement as a judgment of the court. ${ }^{53}$ In the international space, UNCITRAL has recently agreed the text of a draft Convention on the Enforcement of Mediation Settlement Agreements which evidences the progress being made in this field..$^{54}$ ICSID is also not left out in the push for the use of mediation in resolving investment disputes. ${ }^{55}$

Codification of mediation as a process, is gaining traction. OHADA very recently adopted a Uniform Act on Mediation ${ }^{56}$ following the EU Mediation Directive of $2008 .{ }^{57}$ UNCITRAL has also recently proposed a Model Law on International Commercial Mediation as an amendment to its Model Law on International Commercial Conciliation. ${ }^{58}$ There are various arguments on both sides of the mediation codification debate. However, in our view, it is the flexibility of the process that makes mediation attractive. If codification becomes prescriptive and causes mediators and parties the loss of their imagination in working out creative solutions to intractable disputes, then such codification fails the parties and the process and should not be encouraged.

Thus, mediation, an attractive tool which empowers the parties to find solutions to their disputes with the help of a third party neutral, is a developing system, which must be encouraged. However for now, disputing commercial parties need decisions that are recognised and enforceable by a state if not voluntarily complied with by a party.

\section{Arbitration}

Arbitration is an adjudicative dispute resolution process in which the parties give the control or power to determine their dispute to a neutral third party, the arbitral tribunal. The tribunal determines the

\footnotetext{
${ }^{53}$ See section 4 (b) of the Lagos State Multidoor Court Law 2007 available online at: http://www.lawnigeria.com/RULES-OF-COURTS/LAGOS-STATE-MULTIDOOR-COURT-LAW.html [last visited 26 July 2018].

${ }^{54}$ The text of a Draft Convention was agreed on 26 June 2018 at the $51^{\text {st }}$ Session of UNCITRAL by Working Group II, for the enforcement of international commercial settlement agreements resulting from mediation. See the latest documents from the Working Group deliberations at: https://documents-ddsny.un.org/doc/UNDOC/GEN/V18/008/77/PDF/V1800877.pdf?OpenElement [last visited 26 July].

${ }^{55}$ See notice at: https://icsid.worldbank.org/en/Pages/process/adr-mechanisms--mediation.aspx [last visited 26 July 2018] making reference to the International Bar Association (IBA) Rules for Investor-State Mediation, 2012.

56 OHADA Uniform Act Relating to Mediation 2017 and entered into force on 15 March 2018.

${ }^{57}$ EU Mediation Directive 2008/52/EC available at: https://eur-lex.europa.eu/legalcontent/EN/TXT/PDF/?uri=CELEX:32008L0052\&from=en [last visited 26 July 2018].

${ }^{58}$ See the UNCITRAL Model Law on International Commercial Mediation and International Settlement Agreements Resulting from Mediation, 2018 (amending the UNCITRAL Model Law on International Commercial Conciliation, 2002) available at: http://www.uncitral.org/pdf/english/commissionsessions/51stsession/ACN9-943 advance copy website.pdf [last visited 26 July 2018].
} 
dispute and the rights and obligations of the disputants. In arbitration, the parties need to persuade the arbitral tribunal of the validity of their claims. This is unlike in most mediation processes where the disputants communicate with each other, even when the communication is through a third party neutral. In this way, arbitration is likened to litigation before national courts, only private, and the arbitrator is likened to a private judge. In arbitration therefore, the disputants receive a final determination or decision by the arbitral tribunal over their dispute, just as they do in litigation. This gives some degree of certainty and finality..$^{59}$

Nation states accord a certain status to arbitral awards and the vast majority of African jurisdictions, accord to arbitral awards the same status as a final judgment of their national (first instance) courts. ${ }^{60}$ This status is priceless to arbitration as a private dispute resolution mechanism. It effectively means that the arbitration process covers the equivalent of the first instance court proceeding that would have had jurisdiction over the dispute, only better. The arbitral hearing process is better because the findings of the arbitral tribunal on the facts generally, cannot be reopened and the award can only be challenged on very limited grounds and not open to full blown appeal as the judgment of a national court. ${ }^{61}$ In addition, there are currently 38 African states that are members of the New York Convention under which foreign arbitral awards can be enforced or challenged also on very limited grounds, in 159 jurisdictions globally. ${ }^{62}$

With such currency, can arbitration be attractive for use in cross-border intra-African commercial disputes? An enumeration of the advantages of arbitration will lead to an affirmative answer to this question. However, we note at the outset, that arbitration may not be suitable for all types of disputes and is not designed to replace litigation before national courts. Indeed, arbitration needs a supportive national court to thrive.$^{63}$ Having said that though, it is argued that arbitration will be suitable for the resolution of the vast majority of intra-African commercial disputes.

a) Advantages of Arbitration

According to the 2006 Queen Mary International Arbitration survey, 73\% of the in-house counsel they interviewed, prefer arbitration to litigation. And by the 2008 survey, $88 \%$ of the respondents, had used arbitration and this number rose to $97 \%$ in their latest survey of 2018 , with $99 \%$ of respondents willing to recommend arbitration for use in the resolution of their cross-border disputes. ${ }^{64}$

\footnotetext{
${ }^{59}$ Arbitration awards generally have res judicata effect but are still subject to enforcement and annulment proceedings, though on limited grounds. See for example, Nigel Blackaby and Constantine Partasides with Alan Redfern and Martin Hunter, Redfern and Hunter on International Arbitration, $\left(6^{\text {th }}\right.$ ed., Oxford University Press, 2015) pp. 559-560.

${ }^{60}$ For the position under the laws of various African states, see, John Miles, Tunde Fagbohunlu and Kamal Shah, Arbitration in Africa, a Review of Key Jurisdictions, (Sweet \& Maxwell, 2016); and Lise Bosman (general editor) Arbitration in Africa: A Practitioner's Guide, (Kluwer Law International, 2013).

${ }^{61}$ National arbitration laws also set out the grounds for such challenge. See for example, arts. 34 and 36 of the UNCITRAL Model Law.

${ }^{62}$ The United Nations Convention on the Recognition and Enforcement of Foreign Arbitral Awards, New York, 1958 with text available at: https://uncitral.un.org/sites/uncitral.un.org/files/mediadocuments/uncitral/en/new-york-convention-e.pdf [last visited 17 December 2018]. There are 159 member states as at December 2018.

${ }^{63}$ Emilia Onyema, 'The Jurisdictional Tensions Between Domestic Courts and Arbitral Tribunals', in Andrea Menaker (general editor), International Arbitration and the Rule of Law: Contribution and Conformity, (Kluwer Law International, 2017) pp. 481-492.

${ }^{64}$ The Queen Mary International Arbitration surveys are published every two years and are available at: http://www.arbitration.qmul.ac.uk/research/ [last visited 26 July 2018].
} 
In the same 2006 survey, the top reasons for this choice were, flexibility of procedure, enforceability of awards, privacy of the process, and the ability of the parties to select their arbitrators. ${ }^{65}$ However, according to the 2018 Queen Mary International Arbitration survey, enforceability of awards has become the most important advantage of arbitration, followed by avoiding specific legal systems/national courts, flexibility, and ability to choose arbitrators. ${ }^{66}$ One little acknowledged advantage of arbitration is its positive impact on litigation practice. $64.9 \%$ of the respondents to the 2018 SOAS Arbitration in Africa survey acknowledged this positive impact. ${ }^{67}$ Some examples of how arbitration has positively impacted litigation in some African jurisdictions include, 'the concept of front loading documents and pre-trial conferences'; 'adoption of more flexible, commercial and pragmatic approach by litigators', and, '... approach to litigation tends to be less traditional and more commercial .....$^{68}$

The message from these empirical sources is that commercial parties who transact across borders prefer arbitration as their dispute resolution mechanism of choice.

\section{b) Disadvantages of Arbitration}

In the 2006 Queen Mary International Arbitration survey, the expense (cost) and length of time it took to resolve disputes by arbitration, and risk of court intervention in arbitration, were the top disadvantages of arbitration. ${ }^{69}$ In their 2018 survey, cost, lack of effective sanctions during the process, lack of power against third parties, and lack of speed were the top disadvantages. ${ }^{70}$

Therefore, the cost of prosecuting an arbitration may negatively impact on the choice of arbitration for the resolution of cross-border intra-African commercial disputes especially where MSMEs are parties to the disputes. This is an important determinant. This is primarily because the vast majority of commercial actors in Africa are MSMEs and also operators in the informal sector. As already mentioned, one of the features of operations in the informal sector is the lack of engagement of lawyers, non-written transactions (which are usually based on trust) which are also cash based and thus, may not pass through the banking system. ${ }^{71}$ These features imply that the commercial or trading transactions will not have pre-dispute arbitration agreements in the first place. This may be fatal since without an arbitration agreement, the consensual process of arbitration will not unfold. We acknowledge that such fatality can be cured by the parties entering into a submission (post dispute) arbitration agreement. Though, in practice when a dispute arises, it becomes very difficult to get the parties to agree on anything, least of all, arbitration, which may by itself, remove a perceived 'home advantage' (of litigating before a national court) from one of the parties.

Disputing parties enjoy great powers in arbitration. These powers, which are covered by the principle of party autonomy, are granted by the state (evidenced in the relevant arbitration legislation of each

${ }^{65}$ For the 2006 Queen Mary International Arbitration survey, see:

http://www.arbitration.qmul.ac.uk/research/2006/ [last visited 226 July 2018].

${ }^{66}$ For the 2018 Queen Mary International Arbitration survey see: http://www.arbitration.qmul.ac.uk/research/2018/ [last visited 26 July 2018].

${ }^{67}$ SOAS Arbitration in Africa Survey, Domestic and International Arbitration: Perspectives from African Arbitration Practitioners 2018, available at: http://eprints.soas.ac.uk/25741/ [last visited 26 July 2018].

${ }^{68}$ SOAS 2018 Arbitration survey, Ibid.

${ }^{69} 2006$ Queen Mary International Arbitration survey, Ibid.

${ }^{70} 2018$ Queen Mary International Arbitration survey, Ibid. This effectively puts to rest the assertion that international arbitration is faster and cheaper than litigation. Though in most African jurisdictions, international arbitration will still be faster than litigation but certainly not cheaper.

${ }^{71}$ See for example, Leandro Medina, Andrew Jonelis \& Mehmet Cangul, 'The Informal Economy in Sub-Saharan Africa: Size and Determinants', IMF Working Paper No WP/17/156 available at: file:///C:/Users/eo3/Downloads/wp17156.pdf [last visited 26 July 2018]. 
state). These powers also evidence the confidence the state reposes in the disputing parties to make informed decisions for themselves. Some of these issues, which are relevant to intra-African crossborder transactions, include the determination of the: language of the proceedings, applicable laws and rules to govern both the arbitral procedure and the substantive rights, obligations and remedies of the parties. ${ }^{72}$ The jewel in the crown remains the ability of the disputing parties to appoint the decision makers, the arbitrators. ${ }^{73}$ This is one power the parties cannot exercise in litigation before national courts where a judge is assigned to their case, usually without their input.

These issues are very important and are genuine advantages that make arbitration in some cases, preferable over litigation. Take for example, a transaction between a Nigerian supplier (English), a Beninese middleman (French) and a Mozambican buyer (Portuguese) for delivery of goods in Maputo to be performed by Ethiopian Airlines (English/Amharic). ${ }^{74}$ When a dispute arises between any or all of these parties, which party will want to go to the national courts of the other? None of these parties, will be our answer. But, we can easily envisage the same parties opting for arbitration, even in a third neutral (African) venue.

\section{c) Enforcement of Intra-African Cross Border Arbitral Awards}

One last important point to mention is the enforceability of arbitral awards within the African continent. 38 African states ${ }^{75}$ have ratified and are members of the 159 member-states strong New York Convention for the Recognition and Enforcement of Foreign Arbitral Awards 1958 (New York Convention). ${ }^{76}$ The New York Convention facilitates the recognition and enforcement of foreign arbitration agreements ${ }^{77}$ and awards made in one Convention state, in another Convention state. ${ }^{78}$ There is no equivalent mechanism for the enforcement of foreign court judgments among these 38 (or the 54) African states. ${ }^{79}$ This therefore means that even where parties obtain a judgement from a national court in an African state, they will need to overcome the various (possibly unfamiliar) hurdles to obtain its recognition and enforcement in another African state. ${ }^{80}$ With arbitration, the requirements to obtain the recognition and enforcement of foreign arbitral awards are, at least known. ${ }^{81}$ The arbitral award will still needs to survive the understanding, interpretation and attitude

\footnotetext{
${ }^{72}$ See for example, arts. 19 (rules of procedure), 22 (language), 28 (rules on the substance) of the UNCITRAL Model Law.

${ }^{73}$ See for example, art. 11 of the UNCITRAL Model Law.

74 These are the sorts of transactions envisaged under the AfCFTA.

75 The Convention became effective in Sudan in June 2018. For a list of all African state parties to the New York Convention, see Table 2 below.

${ }^{76}$ For the status and text of the New York Convention, see:

http://www.uncitral.org/uncitral/en/uncitral texts/arbitration/NYConvention status.html [last visited 26 July 2018].

77 In accordance with art. Il of the New York Convention.

78 In accordance with art. I of the New York Convention and this extends to, "arbitral awards not considered as domestic awards in the State where their recognition and enforcement are sought". (English translation).

79 There is no African State that is party to either the 1971 Hague Convention on the Recognition and Enforcement of Foreign Judgments in Civil and Commercial Matters; or the 2005 Hague Convention on Choice of Court Agreements which came into force on 1 October 2015.

${ }^{80}$ See for example, the Chapter on Nigeria by Babatunde Ajibade and Benedict Oregbemhe in The International Comparative Legal Guide to Enforcement of Foreign Judgements, 2016 available at: http://www.spaajibade.com/resources/wp-content/uploads/2016/03/EFJ16 Chapter-23 Nigeria.pdf [last visited 26 July 2018].

${ }^{81}$ For example, for New York Convention awards, see art. IV.
} 
of the enforcing court in the African jurisdiction. ${ }^{82}$ But so long as the judgement debtor has assets in any of the remaining 121 non-African member states of the New York Convention, the judgment creditor can still pursue enforcement of the award in those other jurisdictions, most of which are favourably disposed towards the enforcement of foreign arbitral awards. Thus, as it relates to certainty of the recognition and enforcement of the outcome of the chosen dispute resolution process, the arbitral award has a higher cross-border recognition and enforcement value than the judgment of a national court.

\section{Investment Arbitration}

Where the commercial actor qualifies as a foreign investor and there is a relevant investment agreement or law, the investment related dispute may fall within the investor-state dispute settlement (ISDS) domain. However, most intra African commercial disputes will fall outside the ISDS system for primarily not implicating the state or a state agency as a party to the dispute, and the nature of the dispute not emanating from an investment related regulatory measure taken by the state that causes the investor compensable harm. ${ }^{83}$ Where an African company qualifies as a foreign investor and the state measure that caused the loss complained about, falls within the regulatory actions of the state and is covered under an investment agreement, such dispute may be resolved through international investment arbitration. ${ }^{84}$ This is already happening..$^{85}$

According to statistics from the International Centre for the Settlement of Investment Disputes (ICSID) for example, African investors are increasingly becoming claimants in investment arbitration and conciliation disputes. ${ }^{86}$ Interestingly, most of these African investors sue African states. ${ }^{87}$ This is understandable since those are the states that predominantly host their investments. With the commencement of negotiations of the investment chapter of the AfCFTA, ${ }^{88}$ the publication of the text of the Pan-African Investment Code (PAIC), ${ }^{89}$ and the various regional investment regulations, ${ }^{90}$ it is anticipated that there will be an increase in this regime of disputes between African states and African investors and investment entities.

\footnotetext{
${ }^{82}$ See for analyses of the attitudes of the courts of some African States on the enforcement of arbitral awards, the various contributors in, Emilia Onyema (ed.,) Rethinking the Role of African National Courts in Arbitration, (Kluwer Law International, 2018).

${ }^{83}$ Such measure by a state may include failure to grant national treatment, fair and equitable treatment, most favoured nation treatment and full security to the investment of the foreign investor.

${ }^{84}$ For the definition of an investment dispute, see for example, R. Doak Bishop, James R. Crawford and W. Michael Reisman, Foreign Investment Disputes: Cases, Materials and Commentary, $\left(2^{\text {nd }}\right.$ ed., Kluwer Law International, 2014) at p. 10.

${ }^{85}$ For example, Global Telecom Holding SAE (Egyptian) v Canada, ICSID Case No. ARB/16/16.

${ }^{86}$ See the ICSID Caseload: Statistics Special Focus on Africa (May 2017) at pages 20-27 (available online).

${ }^{87}$ ICSID Statistics, Ibid, at p. 13 notes that "in the 135 ICSID cases involving an African State party, $21 \%$ were commenced by an African investor".

${ }^{88}$ Negotiation of the Investment Protocol of the AfCFTA commenced in June 2018.

89 The Pan-African Investment Code was agreed under the auspices of the AU and for some commentary see, Makane Moïse Mbengue and Stefanie Schacherer, 'The 'Africanization' of International Investment Law: the Pan-African Investment Code and the Reform of the International Investment Law Regime', Volume 18, Journal of World Investment and Trade, (2017) p. 414. The text of the draft PAIC is available at: https://au.int/en/documents/20161231/pan-african-investment-code-paic [last visited 26 July 2018].

${ }^{90}$ Examples are: The Investment Agreement for the COMESA Common Investment Area, signed 23 May 2007 and under revision; the Community Rules on Investment of the ECOWAS, signed 19 December 2008 and entered into force 19 January 2009; the SADC Protocol on Finance and Investment, signed 18 August 2006 and entered into force 16 April 2010; and SADC Model Bilateral Investment Treaty template published in 2012; and the EAC Model Investment Code drafted in 2002.
} 
It can therefore, be concluded that, for purely commercial disputes, recourse to arbitration for the determination of cross-border intra-African commercial disputes, will be the preferred option in comparison to either recourse to litigation before national courts or non-adjudicative processes, such as mediation.

\section{Arbitration of Intra-African Commercial Disputes}

This section explores the current framework for the arbitration of intra-African commercial disputes and re-imagines this framework to argue for a more effective regime that will contribute to the attainment of the vision behind the AfCFTA. To reimagine, it is important to understand what already exists and examine whether the current system remains fit for purpose. This section shall therefore discuss the current regimes for the arbitration of intra-African commercial disputes (1) and thereafter, reimagine the current framework by exploring some ideas on how the current system can be improved to better serve its users (2).

\section{Current Arbitration Framework for intra-African Commercial Disputes}

As already mentioned, arbitration is a recognised dispute resolution mechanism in practically all African states, particularly for the resolution of commercial or business disputes. In support of this process, all but one, of the states in Africa (South Sudan) have enacted into law, modern (and in some cases not so modern) arbitration legislations. ${ }^{91}$ Though there is no continent-wide arbitration law, ${ }^{92}$ there is a uniform arbitration law binding on the seventeen OHADA member states..$^{93}$ Some of these national legislations are currently under review while, in our view, a majority of the laws need to be reviewed to modernise their provisions so they remain fit for use by sophisticated commercial parties. Interestingly, 55\% of the respondents to the 2018 SOAS Arbitration in Africa survey, believe their national arbitration laws are effective with $45 \%$ believing their national arbitration laws are not effective or need review. ${ }^{94}$ Thus there is legislative framework for the operation of arbitration in almost all African countries evidencing the acceptance of the dispute resolution mechanism by African states.

The second evidence of the supportive regime for arbitration in Africa is the availability of arbitration centres or institutions that administer arbitration references under their bespoke or other arbitration rules. One count in 2015, lists 71 of such centres in 39 African countries. ${ }^{95} \mathrm{It}$ is not very clear how busy all of these centres are, but for those centres that publish their annual statistics, such as the Cairo Regional Centre for International Arbitration (CRCICA) and the Kigali International Arbitration Centre (KIAC), they have recorded year-on-year increases in their caseload. For example, CRCICA, in the first quarter of 2018, registered 20 new cases against 16 at the same time in 2016; and since its inception in $1979,1,246$ cases have been filed with the centre. ${ }^{96} \mathrm{KIAC}$ on its part, has as at beginning of December 2018, registered 97 cases since it opened for business in $2012 .{ }^{97}$ These are encouraging

\footnotetext{
${ }^{91}$ See Table 2 below for a list of these national arbitration laws.

92 This is in the sense of a similar agreement to the European Convention on International Commercial Arbitration of 1961 available at: https://treaties.un.org/pages/ViewDetails.aspx?src=TREATY\&mtdsg no=XXII2\&chapter $=22 \&$ clang= en [last visited 26 July 2018].

93 The Uniform Arbitration Act, 1999 was revised in November 2017 effective March 2018.

${ }^{94}$ SOAS Arbitration in Africa Survey at p. 32.

${ }^{95}$ See list of arbitration centres in Africa compiled by Dr Emilia Onyema of SOAS University of London at: https://docs.wixstatic.com/ugd/ef6df1 a0f973bbbbb14c7b8d733ba7c58f6a0b.pdf [accessed 26 July 2018].

${ }^{96}$ See details at: http://crcica.org/NewsDetails.aspx?ID=28 [last visited 11 July 2018].

${ }^{97}$ This information was provided by Dr Fidele Masengo the Secretary General of KIAC in the recently published KIAC caseload available at: https://www.kiac.org.rw/IMG/pdf/kiac growing caseload.pdf [last visited 26 July 2018].
} 
statistics and it is expected that there will be an increase in the caseload of the various centres as the AfCFTA beds down and the projected increase in intra-African trade in goods, services and investments materialise.

There are also major arbitration centres in each region of the continent. For example, the CRCICA in North Africa, KIAC and the Nairobi Centre for International Arbitration $\left(\mathrm{NCIA}^{98}\right)$ in East Africa; the OHADA CCJA ${ }^{99}$ in the OHADA region; the Arbitration Foundation of South Africa (AFSA ${ }^{100}$ ) in Southern Africa; the Lagos Regional Centre for International Commercial Arbitration ${ }^{101}$ (another AALCO centre ${ }^{102}$ ) and the Ghana Arbitration Centre (GAC) in West Africa. ${ }^{103}$ Thus, Africa does not lack arbitration centres. What needs to be interrogated is the experience and effectiveness of the centres in performing their tasks, and how they collaborate (if at all) with each other, and share their spaces. ${ }^{104}$ To support this task of collaboration, the first SOAS Arbitration in Africa conference was held in Addis Ababa in 2015 to interrogate the role of the arbitral centres in supporting the development of arbitration in Africa. ${ }^{105}$ This conference brought together the leaders of many of the arbitration centres operating in Africa, who thereafter, formed relationships. It is hoped that these relationships will blossom into proper coordination and support for each other and sharing of best practices, going forward.

As already mentioned, arbitration needs a supportive judiciary to thrive. African courts and judges, over the years, have started making the transition from aversion to support for commercial arbitration. ${ }^{106}$ Such support must be sustained through the continued: training of judges, engagement between the national and continental arbitration communities, and African judiciaries, publication of arbitration-related judgements from African judiciaries, and increased expert support for African legislatures revising their arbitration laws. ${ }^{107}$

The fourth limb of support for an effective arbitration regime in Africa, is the availability of arbitration practitioners who are trained and have experience to discharge the functions of arbitrator, counsel

\footnotetext{
${ }^{98}$ For information on the NCIA, see: https://ncia.or.ke/ [last visited 26 July 2018].

${ }^{99}$ For information on the OHADA CCJA, see: http://www.ohada.org/index.php/en/case-law [last visited 26 July 2018].

${ }^{100}$ For information on the AFSA, see: http://www.arbitration.co.za/pages/default.aspx [last visited 26 July 2018].

${ }^{101}$ For information on the Lagos Regional Centre, see: http://www.rcicalagos.org/ [last visited 26 July 2018].

${ }^{102}$ AALCO is the Asia-Africa Legal Consultative Organisation, the sponsoring agency of the Cairo, Lagos and Nairobi Regional Centres for International Commercial Arbitration in Africa. See for more information on AALCO: http://aalco.int/Scripts/default.asp [last visited 26 July 2018].

${ }^{103}$ It is very encouraging that all of these centres (with the exception of the GAC) have dedicated and functioning websites. To this list can be included the new $\mathrm{MCCl}$ Arbitration and Mediation Centre in Mauritius. ${ }^{104}$ See for a discussion on these issues as it relates to West Africa, Emilia Onyema, "“Regional Arbitration Institution for ECOWAS: Lessons from OHADA Common Court of Justice and Arbitration", Issue 5, International Arbitration Law Review, [IALR] (2014) 99 at pp. 109-111.

${ }^{105}$ For the 2015 Addis Ababa SOAS Arbitration in Africa conference discussion paper, see: http://eprints.soas.ac.uk/20421/ [last visited 26 July 2018].

106 The second SOAS Arbitration in Africa conference, hosted by the Lagos Court of Arbitration centre in 2016 explored how judges can better support the development of arbitration in Africa and the discussion paper is available at: http://eprints.soas.ac.uk/22727/ [last visited 26 July 2018].

107 See for example, Edward Torgbor, 'Overview of the disposition of Courts Towards Arbitration in Africa' and Leyou Tameru, 'Publication and Access to Arbitration Related Decisions from African Courts', in Emilia Onyema (ed.), Rethinking the Role of African National Courts in Arbitration, (Kluwer Law International, 2018) at p. 39 and p. 67 respectively.
} 
and tribunal secretary in arbitration references. ${ }^{108}$ The SOAS Arbitration in Africa 2018 survey revealed that there are many trained arbitration practitioners in Africa but they are not evenly spread across the continent. ${ }^{109}$ This basically implies that there are swathes of the continent with shortages of qualified arbitration practitioners to take on the tasks when the increase in disputes materialise. One solution to this shortage is the provision of training in the jurisdictions that lack trained arbitration practitioners, preferably, by other qualified African arbitration practitioners.

One disturbing finding from the SOAS Arbitration in Africa survey, is that most of the arbitration practitioners do not have practical experience of sitting as arbitrator, acting as counsel in arbitration or acting as tribunal secretary. Over the five year reporting period, only $10 \%$ of the respondents sat as arbitrator in over ten domestic arbitration references; $22 \%$ acted as counsel in six or more domestic arbitration disputes; and $22.5 \%$ of respondents had acted as tribunal secretary in domestic references over the same period. ${ }^{110}$ It is critically important that the trained practitioners have opportunities to sit as arbitrators and act as tribunal secretaries in domestic disputes where they can acquire experience in preparation to function in intra-African commercial disputes. African arbitration centres and appointing authorities may have a role to play in engaging trained African arbitration practitioners to sit as arbitrators and act as tribunal secretaries.

Aligned to this limb, is the need for the establishment of an umbrella continental arbitration organisation that can coordinate some of these tasks and maintain the momentum created by the SOAS Arbitration in Africa conference series (2015-2018) and the ICCA Mauritius Congress of 2016. ${ }^{111}$ Such an association, formally known as, the African Arbitration Association (AfAA) was launched on 29 June 2018 in Abidjan. ${ }^{112}$ The four limbs on which an effective arbitration regime can stand (modern arbitration laws, supportive courts, arbitration centres, and arbitration practitioners) exist on the continent. These support the development and growth of arbitration in Africa, particularly in the context of the disputes that will emanate from intra-African trade as a consequence of the implementation of the AfCFTA. The AfAA will be expected to coordinate the various efforts to ensure that arbitration receives the attention it needs at the continental level.

\section{Re-imagination of the Framework}

Some of the gaps in the effective utilisation of arbitration for intra-African commercial disputes mentioned above point to the need to reimagine the current framework. To do this, and in light of the goals of the AfCFTA (greater African integration), this section will explore two proposals. The first is the need to designate 'Regional Arbitration Centres' across the continent to administer intra-African commercial disputes; and such centres may be closely linked to particular RECs as the identified

\footnotetext{
108 The fourth SOAS Arbitration in Africa conference hosted by the Kigali International Arbitration Centre in Kigali in 2018 explored how arbitration practitioners can support the development of arbitration in Africa. See discussion paper at: https://docs.wixstatic.com/ugd/ef6df1 86bf8269d9a74e6b9a9bc02a7098e204.pdf [accessed 26 July 2018].

109 SOAS Arbitration in Africa Survey, pp. 23-24.

110 Ibid, pp. 17-19.

${ }^{111}$ The International Council for Commercial Arbitration (ICCA) held its first congress in Africa in Mauritius on the theme, 'International Arbitration and the Rule of Law: Contribution and Conformity' from 8-11 May 2016. Details of the conference are available at: http://www.iccamauritius2016.com/Default.aspx [last visited 26 July 2018].

${ }^{112}$ For more information on the AfAA, see: http://www.africanarbitrationassociation.org/ [last visited 26 July 2018].
} 
building blocks of the African Economic Commission (a). ${ }^{113}$ The second proposal will be to establish an African Commercial Court (b). These proposals are focused on removing intra-African commercial arbitration references and the enforcement of the outcome, the award, from purely national or domestic constraints.

\section{(a) Designating Regional Arbitration Centres}

The proposal to link these Regional Arbitration Centres (RACs) to the RECs firstly recognises that in some states, there are no active arbitration centres. ${ }^{114}$ Secondly and in recognition of the role assigned to the RECs in delivering the goals of the AfCFTA, the geographical spread of the eight RECs recognised by the African Union. ${ }^{115}$ From the list of state membership of the RECs under Table 1 below, it is apparent that there are overlapping memberships of African states in the RECs. The Economic Commission for Africa (ECA) and the AU have noted that this overlapping memberships is responsible for the inability of African States to, 'honour their contribution obligations, low programme implementation, low meeting attendance, and duplication or conflicting programme implementation'. ${ }^{116}$

These multiplicity of REC memberships can however, be turned into a positive attribute in determining the arbitral centre to use by disputants. The proposal on designating RACs shall not include hard borders but it is to ensure that there are viable arbitral centres in the geographical space of each REC that disputants can confidently access and which can efficiently deliver the services such disputants need.

The major arbitral centres in the relevant regions such as the CRCICA (Egypt) and Casablanca International Mediation and Arbitration Centre (CIMAC, Morocco ${ }^{117}$ ) in North Africa; KIAC (Rwanda) and NCIA (Kenya) in East Africa; OHADA CCJA (Cote d'Ivoire) for Francophone West and Central Africa; Lagos Regional Centre (Nigeria) and Ghana Arbitration Centre (Ghana) for English West Africa; and in Southern Africa, (AFSA) and the Mauritius Chamber of Commerce and Industry Arbitration Centre $\left(\mathrm{MCCl}^{118}\right)$. These arbitral centres can be endorsed as regional hubs for the arbitration of intra-African commercial disputes. ${ }^{119}$ To ensure a fair distribution of arbitration references across African states, these centres will need to be willing to administer references seated outside their location or domicile and under their arbitration rules. Most of these centres already offer such services which will give disputants greater choice.

\footnotetext{
${ }^{113}$ The following suggestions build on my publication, Emilia Onyema, "Regional Arbitral Institution for ECOWAS: Lessons from OHADA Common Court of Justice and Arbitration", Issue 5, International Arbitration Law Review, [IALR] (2014) 99.

${ }^{114}$ According to the data collected by the author in 2015, there were then 71 arbitral centres in 39 African states leaving 15 states without any known arbitral centres. The list is available at: https://www.researcharbitrationafrica.com/arbitration-institutions-in-africa [last visited 26 July 2018]

${ }^{115}$ See Table 1 below for the list and membership of the eight RECs recognised by the AU.

${ }^{116}$ See for example, the joint publication by the Economic Commission for Africa (ECA) and the African Union (AU), “Assessing Regional Integration in Africa II: Rationalizing Regional Economic Communities", 2006 at pp. 50-55, and available online at: https://www.uneca.org/sites/default/files/PublicationFiles/aria2 eng.pdf [last visited 26 July 2018]. The overlapping memberships was described in the publication as the 'spaghetti bowl'. ${ }^{117}$ For information on CIMAC, see: http://cimac.ma/ [last visited 26 July 2018].

${ }^{118}$ For information on $\mathrm{MCCl}$, see: https://www.mcci.org/en/our-services/arbitrationmediation/arbitration/introduction-to-marc-arbitration/ [last visited 26 July 2018].

119 These centres are the most well-known on the continent. However, such designation must be based on objective evidence of the experience of each centre to discharge the tasks of administering arbitration references to an international standard.
} 
The RACs will need to expand their arbitrator panel lists to be more inclusive, and also allow disputants to select non-listed persons (who are duly qualified) as arbitrators. Though the RACs will be identified and actively promoted to administer the arbitration of intra-African disputes, disputants will not be limited to appointing such centres, and may choose other centres (within and outside the continent) for the resolution of their disputes. In this way, party autonomy is not forfeited and party choice will still take precedence. However, the RACs will receive special mention by member states of the AU and AfCFTA, who will actively encourage disputants to appoint them in their transactions and agreements.

The designation of RACs will serve the dual purpose of identifying those arbitration centres with experience that can administer intra-African disputes, and distinguish them from those centres that administer purely domestic disputes. In this way, the RACs will begin to build reputation for stability and efficiency, comparable to those of such international centres, such as the International Chamber of Commerce, Court of Arbitration (ICC). As already mentioned, there are several arbitration centres operating on the continent but information on the exact services they render and their experience is sparse. Finally, the RAC badge may be one evidence to be used in identifying the more viable centres.

\section{(b) Establishment of an African Commercial Court}

The second re-imagining of the current arbitration framework in Africa, is the proposal to establish a continental level court for the enforcement of intra-African arbitral awards arising from commercial disputes. If we recall one of the findings from the Queen Mary 2018 survey report, the most important benefit of arbitration to its users, is the enforcement of the award emanating from the process. From the same survey, respondents noted, as one major reason for choosing arbitration, the avoidance of certain legal systems and national courts. It is true, as already noted, that most courts and judges in African states have started the movement towards better support for arbitration, but this is still in its early stages and eclectic in some states, and by no means uniform across the continent. ${ }^{120}$ This lack of uniformity of treatment of such an important aspect of arbitration, makes it imperative that an effective and efficient mechanism is designed to ensure the fast and effective enforcement (or annulment) of such arbitral awards. Issues on court interference during the arbitral reference is excluded from this discussion. This is primarily because the basis on which to construct a continentwide arbitration legislation or convention and the political will to drive such a legal document may not exist in the current state of affairs in Africa. More importantly is that for now, there is no empirical data to suggest that the arbitration laws operating in African states are not satisfactory. To the contrary, only $12 \%$ of the respondents to the SOAS Arbitration in Africa survey believe their national arbitration law is not effective, ${ }^{121}$ reducing the priority level at this time, of the need for a continental arbitration treaty. ${ }^{122}$

This section therefore briefly explores whether the creation of an African Commercial Court (ACC) for the enforcement and annulment of cross-border African arbitral awards, as a one stop court, will create such enabling environment and confidence in the greater recourse to arbitration for the resolution of intra-African commercial disputes. To actualise this proposal, several issues will need to be settled. Some of these issues can be divided into jurisdictional (i), and operational (ii) issues. There are also some hindrances (iii) to the actualisation of the proposal.

\footnotetext{
${ }^{120}$ See for examples, the contributions in Part 2 in Emilia Onyema (ed.,) Rethinking the Role of African National Courts in Arbitration, Ibid.

${ }^{121}$ SOAS Arbitration in Africa survey 2018, at p. 32 though the author of the survey notes that, 'for complex disputes, most of these national laws will need to be reviewed and updated if they are to meet the expectations of contemporary arbitration disputants'.

${ }^{122}$ As noted above under D.1, we disagree with this view from the survey respondents, but that is the evidence we currently have on the fitness of these national arbitration laws.
} 


\section{i) Jurisdictional Issues}

The ACC is proposed to be a continental supranational court and as such, its jurisdiction and its limitations must be clearly formulated. This proposal is targeted at limiting the jurisdiction of the court to the enforcement and challenge of arbitral awards from disputes over intra-African trade in goods and services. This jurisdiction may later be expanded to include international awards. ${ }^{123}$ As part of the jurisdictional issues, the procedure of the ACC will also include clear and strict timelines. This will ensure that enforcement or challenge applications are determined with despatch and without undue delay. ${ }^{124}$

\section{ii) Operational Issues}

This proposal is for either a wholly new court or a Chamber of the African Court ${ }^{125}$ to be established and granted this jurisdiction. This proposal is not new, though different. For example, the UNECA in its 2016 Report, Investment Policies and Bilateral Investment Treaties in Africa: Implications for Regional Integration, suggested the establishment of a similar court as a branch of the African Court. ${ }^{126}$ Another strong proponent of a continental court is Chrispas Nyombi, who proposed the establishment of a pan-African Investment Court for, 'intra-Africa investment agreements and investment disputes'. ${ }^{127}$ These proposals focus on investment disputes not purely commercial disputes as is proposed for the ACC.

The ACC proposal will be for judges of the new court (or Chamber of the African Court) to be selected from experts in arbitration or arbitration practitioners or judges from different African countries. It is also proposed that all member states of the AU and AfCFTA will commit to honour and enforce the decision of this special court and treat such decision as equivalent to a final decision of their Supreme or highest national Courts (or for the OHADA region, the CCJA). In this manner, the ACC will effectively have coordinate jurisdiction with the Supreme Courts (or CCJA) in matters that fall within its jurisdiction.

\section{iii) Possible Hindrances}

There are a number of possible hindrances to the actualisation of this proposal. The most obvious hindrance is the cost of establishing a new court. In our view, there are various ways the court can be funded. It can be funded by the state parties to the AfCFTA (with a surcharge for citizens of nonmember AfCFTA states seeking to use the court); or by the users of the court through the payment of court fees. The disadvantage of the users funding the operation of the court is that it will add to the cost of doing business within the continent and may also price out MSMEs from making recourse to the court. The second hindrance is the availability of the political will of the heads of African states and governments to donate some of their sovereignty to this supranational continental court.

It will be useful to briefly explore any examples of similar courts operating on the continent. The OHADA CCJA, as already mentioned, is an example of a supranational court that is functional within

\footnotetext{
${ }^{123}$ International awards may include foreign awards, which by their very nature may be domestic awards.

124 The revised OHADA Arbitration Act 2017 and the revised Arbitration Rules of the CCJA, include very short time limits. For example, the CCJA will determine appeals on award challenges within six months from the date of referral according to art. 27 OHADA Uniform Act on Arbitration and art. 29 CCJA Arbitration Rules.

125 The African Court is currently a human and peoples' rights court. See: http://www.africancourt.org/en/index.php/12-homepage1/1-welcome-to-the-african-court [last visited 26 July 2018]

${ }^{126}$ The UNECA Report (2016), at p. 46, suggests, 'The continent could consider a pan-African solution such as the African Court of Justice ... (to) be used for the proposed Continental Free trade Area (CFTA) ...' 127 Chrispas Nyombi, 'Towards a New International Economic Order: Proposal for a Pan-African Investment Court', in Emilia Onyema (ed.,) Rethinking the Role of African National Courts in Arbitration, Ibid 117 at pp. 140-141.
} 
the OHADA space. However, the major difference between the operation of the CCJA and the proposed African Commercial Court (ACC) is that the ACC shall not act as an appellate court that will hear appeals from African national courts. The ACC shall be a one-stop continental court with limited jurisdiction over final arbitral awards emanating from the arbitration of intra-African commercial disputes. African states will donate some of their sovereignty as it relates to the adjudication of matters falling within the jurisdiction of the ACC. Disputants will have the option to choose to either bring their application before the ACC or pursue their claim before a national court. At the time they choose one option, they forfeit their right of access to the second option. This has the advantage of preserving party choice and the opportunity for African national courts to determine such disputes which may be referred to them.

The second example of a court that operates in the fashion proposed, is the International Arbitration Courts in Mauritius over which three 'Designated Judges' preside. ${ }^{128}$ One difference with the procedure under the Mauritian International Arbitration Act and the proposed ACC, is that there shall be no appeals, least of all, such appeals lying to the Judicial Committee of the Privy Council as is the case in Mauritius. The Mauritian judges are specially trained in arbitration matters. ${ }^{129}$ The judges of the ACC can also be specially trained in both arbitration and general commercial law, to equip them to determine the applications for the enforcement or annulment of awards which will come before them.

One relevant question at this stage relates to the enforcement or execution of the decisions of the ACC. The proposal here is to adopt the enforcement system under both the OHADA CCJA ${ }^{130}$ and the East African Community Court of Justice ${ }^{131}$ regimes, for decisions of the ACC. All that will be required for a national court or registry to enforce the decision of the ACC will be the verification of the authenticity of the stamp or order as emanating from the African Commercial Court, upon application for enforcement by an applicant. National courts will be required to treat the judgement from the ACC as equivalent to the judgement of their Supreme Courts. In this manner, immediately a judge (or Court Registrar) confirms the authentication of the stamp or order of the ACC, an enforcement order will be issued and the internal processes of the enforcing jurisdiction for the execution of judgments in each African state will be followed.

This proposal deals with the problem of weak court systems and the attendant difficulties with the enforcement of arbitral awards in African countries. It creates the opportunity for the ACC to contribute to the interpretation and understanding of internationally accepted grounds for the enforcement or challenge of arbitral awards, for example, under the New York Convention and UNCITRAL Model Law.

\section{Conclusion}

This article examined the reference of disputes arising from intra-African commercial transactions to the different types of dispute resolution mechanisms of litigation, mediation and arbitration, and argued that arbitration will be the most appropriate mechanism for the resolution of such disputes. It then explored the current intra-African arbitration framework, identified some gaps and reimagined this framework. It proposed the identification of Regional Arbitral Centres (RACs) spread over the eight

\footnotetext{
128 In accordance with s.43 of the International Arbitration Act of Mauritius, 2008 (amended 2013).

${ }^{129}$ See for more information, Duncan Bagshaw, "The Experience of LCIA-MIAC" in Emilia Onyema (ed.,) The Transformation of Arbitration in Africa: the Role of Arbitral Institutions, (Kluwer Law International, 2016) at p. 102.

${ }^{130}$ Art. 20 OHADA Treaty 1993 (amended 2008).

${ }^{131}$ In accordance with art. 44 of the EAC Treaty and Rule 72(2) of the EACJ Rules of Procedure.
} 
identified RECs by the AU, which will be actively promoted to administer arbitration references on disputes emanating from intra-African commercial transactions. To assure the effective judicial support for the arbitration of intra-African disputes and the enforcement or annulment of the awards from such references, this article proposed the creation of an African Commercial Court with the sole jurisdiction of enforcing or nullifying arbitral awards from such intra-African arbitration references. Decisions of the ACC would be directly enforceable in all member states of the AU and the AfCFTA. These proposals do not exclude revisiting in the future, the possibility of concluding a continental arbitration law. The implementation of these proposals will ensure that arbitration as the dispute resolution of choice by commercial parties, will play its supportive role for the actualisation of the goals of greater intra-African trade in goods, services and investment, envisioned in the AfCFTA. 
Table 1: African States and REC Memberships as at 26 July 2018

\begin{tabular}{|c|c|c|c|c|c|c|c|c|c|c|}
\hline No & State & $\begin{array}{l}\text { CEN- } \\
\text { SAD }\end{array}$ & COMESA & EAC & ECCAS & ECOWAS & IGAD & SADC & AMU & WTO \\
\hline 1 & Algeria & & & & $x$ & & & $x$ & $x$ & Obs \\
\hline 2 & Angola & & & & & & & & & $x$ \\
\hline 3 & Benin & $x$ & & & & $x$ & & & & $x$ \\
\hline 4 & Botswana & & & & & & & $\mathrm{x}$ & & $x$ \\
\hline 5 & Burkina Faso & $x$ & & & & $\mathrm{x}$ & & & & $x$ \\
\hline 6 & Burundi & & $\mathrm{x}$ & $x$ & $x$ & & & & & $x$ \\
\hline 7 & Cabo Verde & & & & & $x$ & & & & $x$ \\
\hline 8 & Cameroon & & & & $x$ & & & & & $x$ \\
\hline 9 & $\begin{array}{l}\text { Central Africa } \\
\text { Republic }\end{array}$ & $x$ & & & $x$ & & & & & $x$ \\
\hline 10 & Chad & $\mathrm{X}$ & & & $x$ & & & & & $x$ \\
\hline 11 & Comoros & $x$ & $\mathrm{X}$ & & & & & & & Obs \\
\hline 12 & Cote d'Ivoire & & & & & $x$ & & & & $\mathrm{X}$ \\
\hline 13 & $\begin{array}{l}\text { Democratic } \\
\text { Republic of } \\
\text { Congo }\end{array}$ & & $x$ & & $x$ & & & $x$ & & $x$ \\
\hline 14 & Djibouti & $x$ & $x$ & & & & $x$ & & & $x$ \\
\hline 15 & Egypt & $x$ & $x$ & & & & & & & $x$ \\
\hline 16 & $\begin{array}{l}\text { Equatorial } \\
\text { Guinea }\end{array}$ & & & & $x$ & & & & & Obs \\
\hline 17 & Eritrea & $x$ & $x$ & & & & $x$ & & & \\
\hline 18 & Ethiopia & & $x$ & & & & $x$ & & & Obs \\
\hline 19 & Gabon & & & & $x$ & & & & & $x$ \\
\hline 20 & Gambia & $x$ & & & & $x$ & & & & $x$ \\
\hline 21 & Ghana & $\mathrm{X}$ & & & & $\mathrm{x}$ & & & & $x$ \\
\hline 22 & Guinea & $x$ & & & & $x$ & & & & $x$ \\
\hline 23 & Guinea Bissau & $\mathrm{X}$ & & & & $\mathrm{x}$ & & & & $x$ \\
\hline 24 & Kenya & $x$ & $\mathrm{x}$ & $\mathrm{x}$ & & & $x$ & & & $x$ \\
\hline 25 & Lesotho & & & & & & & $\mathrm{x}$ & & $x$ \\
\hline 26 & Liberia & $\mathrm{x}$ & & & & $x$ & & & & $x$ \\
\hline 27 & Libya & $x$ & $\mathrm{x}$ & & & & & & $x$ & Obs \\
\hline 28 & Madagascar & & $x$ & & & & & $x$ & & $x$ \\
\hline 29 & Malawi & & $x$ & & & & & $\mathrm{x}$ & & $x$ \\
\hline 30 & Mali & $\mathrm{x}$ & & & & $\mathrm{x}$ & & & & $x$ \\
\hline 31 & Mauritania & $x$ & & & & & & & $x$ & $x$ \\
\hline 32 & Mauritius & & $x$ & & & & & $\mathrm{x}$ & & $x$ \\
\hline 33 & Morocco & $x$ & & & & & & & $x$ & $x$ \\
\hline 34 & Mozambique & & & & & & & $\mathrm{x}$ & & $x$ \\
\hline 35 & Namibia & & & & & & & $\mathrm{x}$ & & $x$ \\
\hline 36 & Niger & $x$ & & & & $x$ & & & & $x$ \\
\hline 37 & Nigeria & $x$ & & & & $x$ & & & & $x$ \\
\hline 38 & $\begin{array}{l}\text { Republic of } \\
\text { Congo }\end{array}$ & & & & $x$ & & & & & $x$ \\
\hline 39 & Rwanda & & $x$ & $x$ & & & & & & $x$ \\
\hline 40 & Sahrawi ADR & & & & & & & & & \\
\hline 41 & $\begin{array}{l}\text { Sao Tome \& } \\
\text { Principe }\end{array}$ & $x$ & & & $x$ & & & & & Obs \\
\hline 42 & Senegal & $x$ & & & & $x$ & & & & $x$ \\
\hline 43 & Seychelles & & $x$ & & & & & $x$ & & $x$ \\
\hline 44 & Sierra Leone & $x$ & & & & $x$ & & & & $x$ \\
\hline 45 & Somalia & $x$ & $x$ & & & & $x$ & & & Obs \\
\hline
\end{tabular}




\begin{tabular}{|c|c|c|c|c|c|c|c|c|c|}
\hline 46 & South Africa & & $x$ & & & & $x$ & & $x$ \\
\hline 47 & South Sudan & & $x$ & & & $x$ & & & Obs \\
\hline 48 & Sudan & $x$ & $x$ & & & $x$ & & & Obs \\
\hline 49 & Swaziland & & $x$ & & & & $x$ & & $x$ \\
\hline 50 & Tanzania & & & $x$ & & & $x$ & & $x$ \\
\hline 51 & Togo & $x$ & & & $x$ & & & & $x$ \\
\hline 52 & Tunisia & $x$ & $x$ & & & & & $x$ & $x$ \\
\hline 53 & Uganda & & & $x$ & & $x$ & & & $x$ \\
\hline 54 & Zambia & & $x$ & & & & $x$ & & $x$ \\
\hline 55 & Zimbabwe & & $x$ & & & & $x$ & & $x$ \\
\hline
\end{tabular}

Legend:

CEN-SAD: Community of Sahel-Saharan States

COMESA: Common Market for Eastern and Southern Africa

EAC: East African Community

ECCAS: Economic Community of Central African States

ECOWAS: Economic Community of West African States

IGAD: Intergovernmental Authority on Development

SADC: Southern African Development Community

AMU: Arab Maghreb Union

WTO: World Trade Organisation [Obs: observer government] 
Table 2: African States: Arbitration Laws and Membership of the New York Convention as at 26 July 2018

\begin{tabular}{|c|c|c|c|}
\hline No & African State & National Arbitration Legislation & $\begin{array}{l}\text { New York } \\
\text { Convention }\end{array}$ \\
\hline 1 & Algeria & Arbitration Law No 08-09, 2008 & $\mathrm{X}$ \\
\hline 2 & Angola & Voluntary Arbitration Law 2003 & $\mathrm{X}$ \\
\hline 3 & Benin Republic & OHADA Uniform Arbitration Act (revised 2018) & $\mathrm{X}$ \\
\hline 4 & Botswana & Arbitration Act 1959 & $\mathrm{X}$ \\
\hline 5 & Burkina Faso & OHADA Uniform Arbitration Act (revised 2018) & $\mathrm{X}$ \\
\hline 6 & Burundi & Civil Procedure Code 2004 & $\mathrm{X}$ \\
\hline 7 & Cabo Verde & Arbitration Law 2005 & $\mathrm{X}$ \\
\hline 8 & Cameroon & OHADA Uniform Arbitration Act (revised 2018) & $\mathrm{X}$ \\
\hline 9 & $\begin{array}{l}\text { Central Africa } \\
\text { Republic }\end{array}$ & OHADA Uniform Arbitration Act (revised 2018) & $\mathrm{X}$ \\
\hline 10 & Chad & OHADA Uniform Arbitration Act (revised 2018) & - \\
\hline 11 & Comoros & OHADA Uniform Arbitration Act (revised 2018) & $\mathrm{X}$ \\
\hline 12 & Congo Republic & OHADA Uniform Arbitration Act (revised 2018) & - \\
\hline 13 & $\begin{array}{l}\text { Democratic } \\
\text { Republic of Congo }\end{array}$ & OHADA Uniform Arbitration Act (revised 2018) & $\mathrm{x}$ \\
\hline 14 & Cote d'Ivoire & OHADA Uniform Arbitration Act (revised 2018) & $\mathrm{X}$ \\
\hline 15 & Djibouti & Code of International Arbitration 1984 & $\mathrm{X}$ \\
\hline 16 & Egypt & Arbitration Law 1994 (amended 1997) & $\mathrm{X}$ \\
\hline 17 & Equatorial Guinea & OHADA Uniform Arbitration Act (revised 2018) & - \\
\hline 18 & Eritrea & Book IV, Civil Procedure Code 1965 & - \\
\hline 19 & Ethiopia & Civil Procedure Code 1991 & - \\
\hline 20 & Gabon & OHADA Uniform Arbitration Act (revised 2018) & $\mathrm{X}$ \\
\hline 21 & Gambia & Alternative Dispute Resolution Act 2005 & - \\
\hline 22 & Ghana & Alternative Dispute Resolution Act 2010 & $\mathrm{x}$ \\
\hline 23 & Guinea & OHADA Uniform Arbitration Act (revised 2018) & $\mathrm{X}$ \\
\hline 24 & Guinea Bissau & OHADA Uniform Arbitration Act (revised 2018) & - \\
\hline 25 & Kenya & Arbitration Act 2005 (amended 2009) & $\mathrm{X}$ \\
\hline 26 & Lesotho & Arbitration Act No 12 of 1980 & $\mathrm{X}$ \\
\hline 27 & Liberia & Arbitration Law in Commercial Code 2010 & $\mathrm{X}$ \\
\hline 28 & Libya & Code of Civil Procedure 1953 & - \\
\hline 29 & Madagascar & Arbitration Law 98-019 of 1998 & $\mathrm{X}$ \\
\hline 30 & Malawi & Arbitration Act 1967 & - \\
\hline 31 & Mali & OHADA Uniform Arbitration Act (revised 2018) & $\mathrm{X}$ \\
\hline 32 & Mauritania & Code of Arbitration No $2000-06$ & $\mathrm{X}$ \\
\hline 33 & Mauritius & International Arbitration Act 2008 (amended 2013) & $\mathrm{X}$ \\
\hline 34 & Morocco & Code of Civil Procedure 1947 (modified 2007) & $\mathrm{X}$ \\
\hline 35 & Mozambique & Law on Arbitration, Conciliation \& Mediation 1999 & $\mathrm{X}$ \\
\hline 36 & Namibia & Arbitration Act 1965 & - \\
\hline 37 & Niger & OHADA Uniform Arbitration Act (revised 2018) & $\mathrm{X}$ \\
\hline 38 & Nigeria & Arbitration \& Conciliation Act 1988 (under review) & $\mathrm{X}$ \\
\hline 39 & Rwanda & $\begin{array}{l}\text { Arbitration \& Conciliation in Commercial Matters Law } \\
2008\end{array}$ & $\mathrm{x}$ \\
\hline 40 & $\begin{array}{l}\text { Sao Tome \& } \\
\text { Principe }\end{array}$ & Voluntary Arbitration Law 2006 & $\mathrm{X}$ \\
\hline 41 & Senegal & OHADA Uniform Arbitration Act (revised 2018) & $\mathrm{X}$ \\
\hline 42 & Seychelles & $\begin{array}{l}\text { Commercial Code } 1977 \text { \& Code of Civil Procedure } \\
1920\end{array}$ & - \\
\hline
\end{tabular}




\begin{tabular}{|l|l|l|l|}
\hline 43 & Sierra Leone & Arbitration Law Cap 25 Laws of Sierra Leone 1960 & - \\
\hline 44 & Somalia & Civil Procedure Code 1974 & - \\
\hline 45 & South Africa & International Arbitration Law 2017 & X \\
\hline 46 & South Sudan & - & - \\
\hline 47 & Sudan & Arbitration Act 2016 & X \\
\hline 48 & Swaziland (Eswatini) & Arbitration Act 1904 & - \\
\hline 49 & Tanzania & Arbitration Act 2002 & X \\
\hline 50 & Togo & OHADA Uniform Arbitration Act (revised 2018) & - \\
\hline 51 & Tunisia & Arbitration Code 1993 & X \\
\hline 52 & Uganda & Arbitration \& Conciliation Act 2000 (amended 2008) & X \\
\hline 53 & Zambia & Arbitration Act 2000 & X \\
\hline 54 & Zimbabwe & Arbitration Act 1996 & X \\
\hline
\end{tabular}

Table 3: African States: Signatures of the AfCFTA as at 17 December 2018

\begin{tabular}{|c|c|c|c|c|c|}
\hline No & African State & $\begin{array}{l}\text { AfCFTA } \\
\text { Consolidated } \\
\text { Text (Signed) }\end{array}$ & No & African State & $\begin{array}{l}\text { AfCFTA } \\
\text { Consolidated Text } \\
\text { (Signed) }\end{array}$ \\
\hline 1 & Algeria & $x$ & 28 & Libya & $X$ \\
\hline 2 & Angola & $x$ & 29 & Madagascar & $\mathrm{X}$ \\
\hline 3 & Benin Republic & $\mathrm{x}$ & 30 & Malawi & $\mathrm{X}$ \\
\hline 4 & Botswana & - & 31 & Mali & $x$ \\
\hline 5 & Burkina Faso & $\mathrm{x}$ & 32 & Mauritania & $\mathrm{X}$ \\
\hline 6 & Burundi & $x$ & 33 & Mauritius & $x$ \\
\hline 7 & Cabo Verde & $x$ & 34 & Morocco & $x$ \\
\hline 8 & Cameroon & $\mathrm{x}$ & 35 & Mozambique & $\mathrm{X}$ \\
\hline 9 & $\begin{array}{l}\text { Central Africa } \\
\text { Republic }\end{array}$ & $x$ & 36 & Namibia & $x$ \\
\hline 10 & Chad & $x$ & 37 & Niger & $x$ \\
\hline 11 & Comoros & $x$ & 38 & Nigeria & - \\
\hline 12 & Congo Republic & $x$ & 39 & Rwanda & $x$ \\
\hline 13 & $\begin{array}{l}\text { Democratic } \\
\text { Republic of Congo }\end{array}$ & $x$ & 40 & Sao Tome \& Principe & $x$ \\
\hline 14 & Cote d'Ivoire & $\mathrm{x}$ & 41 & Senegal & $x$ \\
\hline 15 & Djibouti & $\mathrm{x}$ & 42 & Seychelles & $x$ \\
\hline 16 & Egypt & $\mathrm{x}$ & 43 & Sierra Leone & $\mathrm{X}$ \\
\hline 17 & Equatorial Guinea & $x$ & 44 & Somalia & $x$ \\
\hline 18 & Eritrea & - & 45 & South Africa & $x$ \\
\hline 19 & Ethiopia & $x$ & 46 & South Sudan & $x$ \\
\hline 20 & Gabon & $x$ & 47 & Sudan & $x$ \\
\hline 21 & Gambia & $\mathrm{x}$ & 48 & Swaziland (Eswatini) & $x$ \\
\hline 22 & Ghana & $\mathrm{x}$ & 49 & Tanzania & - \\
\hline 23 & Guinea & $x$ & 50 & Togo & $x$ \\
\hline 24 & Guinea Bissau & - & 51 & Tunisia & $\mathrm{X}$ \\
\hline 25 & Kenya & $\mathrm{x}$ & 52 & Uganda & $\mathrm{X}$ \\
\hline 26 & Lesotho & $\mathrm{x}$ & 53 & Zambia & - \\
\hline 27 & Liberia & $x$ & 54 & Zimbabwe & $x$ \\
\hline
\end{tabular}

The Saharawi Republic recognised as a sovereign state under the African Union also signed the AfCFTA. 